\title{
NON-AGENDA
}

With the view of causing an increase to take place in the mass of national wealth, or with a view to increase of the means either of subsistence or enjoyment, without some special reason, the general rule is, that nothing ought to be done or attempted by government. The motto, or watchword of government, on these occasions, ought to be - Be quiet. . . Whatever measures, therefore, cannot be justified as exceptions to that rule, may be considered as non-agenda on the part of government.

\section{Coercion by Democracy: The Case of Agricultural Marketing}

\section{David Pearce}

\begin{abstract}
A AN majority rule ever legitimately override individual freedom? The usual argument is that such coercion can be justified only in cases where the costs are outweighed by significant public benefits. Unfortunately, in many instances policy-makers have ignored this principle.

Vaguely democratic arguments for coercive economic arrangements appear in many guises. They cropped up recently in a review of agricultural marketing in Western Australia (CIE, 1995; MSG, 1996) around the issue of the status of a 'single desk seller' for exports of grains.
\end{abstract}

\section{Single Desk Selling}

Single desk export selling has been around a long time in Australia. It is still the federal policy for exports of wheat and remains the main approach in States such as Western Australia for barley, canola and lupins exports. Under single desk selling, a single statutory authority, like the Australian Wheat Board (AWB) or the Grain Pool of Western Australia (GPWA), is given the sole right to purchase particular grains from farmers and to export them (in some cases, it has the sole right to trade domestically also, against the trend towards the liberalisation of domestic trade).

Single desk selling is usually imposed through the compulsory acquisition powers of the statutory marketing authorities, which means that farmers are denied the

\footnotetext{
${ }^{1}$ Farmers can obtain approval from the AWB to export wheat in containers to some destinations. The West Australian government is considering a similar arrangement, subject to GPWA approval.
} 
right freely to sell their own product. Single desk selling usually goes hand in hand with compulsory pooling, under which the total returns from grain sales are divided among farmers by giving each farmer a unit price equivalent to the average pool return.

The implicit justification for these arrangements is that the loss of the farmer's right to sell his or her own product is offset by the single desk seller being able to achieve higher average prices than could be achieved by farmers selling freely. Two broad explanations are offered as to how this may happen. The first holds that the statutory single seller, by virtue of being a monopoly seller of Australian wheat or Western Australian barley, canola, lupins, or whatever, can achieve better returns on export markets than a large number of individual sellers could if they were competing for limited markets. This 'market power' explanation is often interpreted to mean that a single seller can carefully coordinate sales to different markets, thus allowing it to charge different prices in different markets, resulting in increased average returns to growers. A related argument is that a single seller, by having absolute control over sales to different markets, can ensure that any international transport cost advantage that Australia has in selling to particular markets is not competed away by 'too many' sellers bidding against one other.

The second explanation relates to the transactions costs involved in accumulating, storing, and financing a crop to be sold for export. The argument is that a single seller can reduce these various transactions costs, whether by being able to take advantage of economies of scale or by being able to guarantee supply.

These explanations, while not overwhelming, are at least plausible. They are 'in principle' arguments of the kind that people who consider themselves practical usually criticise academics for using. But for them to make sense, single desk selling must be compulsory. To the extent that farmers were free to trade outside the single desk by dealing directly with foreigners, the market power of the single seller would be undermined. Similarly, any farmer trying to finance, accumulate and store his own export shipment would reduce the aggregate gains that could be potential derived from economies of scale. To realise the alleged collective benefits, everyone must be made to play the game.

\section{Do the Benefits Warrant Coercion?}

But not everyone agrees about the alleged benefits of single desk selling. Disagreements come from two sources: economic analysts and farmers who wish to be free to sell their own produce.

Analysts who have tried to quantify the benefits of single desk selling have invariably failed to show significant net benefits. And while it is true that single desk selling may bring benefits to some farmers, there is scant evidence of overall benefits. As well, although a single desk seller may derive benefits from its monopoly over the grain export trade, such benefits come at the expense of other participants in the grain markets.

It is often argued, for example, that marketing authorities such as GPWA can obtain funds at lower interest rates because they can guarantee to market the whole 
export crop. But this lower-cost finance comes at the expense of other players in the grain market (such as processors) who, as a result of the single desk seller's monopoly, have fewer options for using grains, and therefore face a higher risk. The market-power argument is also suspect. The operation of modern grain markets leaves no scope for monopoly power. For example, in canola, all contracts are based on the Winnipeg futures prices, providing little scope for the single seller to extract a higher price from foreigners.

In assessing net benefits, potential costs must be taken into account. The single seller faces the tremendous burden of single-handedly searching out and obtaining the best opportunities in the world market. But it is widely recognised that, for the vast majority of traded products, a large number of players is required to achieve this goal. There is a significant risk that the single seller will simply miss opportunities. As well, the single seller faces no discipline on its behaviour, since there is no way of testing its performance. For example, background research for the review of grain marketing in Western Australia (CIE, 1995) found that many players in the grain market (from farmers to processors) believed that some of the arrangements the GPWA had made were inappropriate. Whether they were appropriate or not is not the issue. The problem is that there is no way of testing them by subjecting them to competition from players who feel they could do better.

The upshot is that many farmers no longer wish to be required to play the single-desk-selling game, because they think they can do better by being allowed to sell freely to whomever they choose. But coercion rules. Most policy-makers appear to accept that single desk export marketing will remain as long as the majority of farmers support it. This was the clear view of the Western Australian government in its response to a ministerial review of grain marketing (MSG, 1996) and of the federal National Party in discussions preceding the federal election of 2 March 1996.

Here, then, is case where a policy imposed by a majority on a minority fails to make a trade-off between individual rights and a collective good and is therefore unjustified. It does not assess the relative benefits and costs of the single desk system. If it could be demonstrated that there were overwhelming net benefits from retaining a single seller, then one might feel happier about limiting the economic freedoms of the minority. But this is not the case.

A second problem is that the 'democracy' that has been used to justify the single seller (both in WA and nationally) is one in which only farmers can vote. But what about other groups whose livelihoods are directly affected by the decision for example, the other players in the grains value chain, including traders, value adders and various other intermediate users? If only farmers are consulted, these other groups have no chance of revealing their interests.

It is interesting to speculate about the reasons why this situation may have emerged. Perhaps it stems from one of the most common economic fallacies in agriculture: that value is created solely at the farm. Whatever the case, the policy of imposing rules on a minority without considering either the costs and benefits or the impact on other economic interests ends up pandering inequitably to one set of interests at the expense of other interests, including the public interest. 


\section{A Policy Challenge}

Managing issues such as single desk selling provides a challenge for any political creed, particularly one that values individual economic freedom. The task is made difficult by the lack of, and difficulty in interpreting, much of the evidence presented by both sides. But policy-makers should take heed of the clear benefits that have already emerged from the partial liberalisation of single desk selling in wheat. And they should beware of taking too narrow a view of democracy.

\section{References}

Centre for International Economics (CIE) (1995), Grain Marketing in Western Australia: A Blueprint for the Future: Report to the Ministerial Steening Group for the WA Grains Industry, Canberra.

Ministerial Steering Group to the Minister for Primary Industry (MSG) (1996), A Strategic Blueprint for the Westem Australian Grains Industry, Perth, January.

David Pearce is Principal Policy Analyst at the Centre for International Economics, Canberra. He would like to thank Sandy Cuthbertson and a referee for comments on an earlier draft.

\section{Delivering Newsagents from Competition}

\section{Ross Jones}

$\mathrm{N}$

EWSAGENTS have a long history of successful lobbying against procompetitive reforms. As the Australian federal election of March 1996 approached, the State-based newsagents' associations again sought support, especially from Liberal-National Coalition candidates, this time in the context of proposed review by the Australian Competition and Consumer Commission (ACCC) of the newsagency system. The review, which is now under way, focuses on the methods of distribution of newspapers and magazines in major States.

\section{The Anti-Competitive Arrangements}

Major newspaper publishers and publishers and distributors of magazines made applications for authorisation under the Trade Practices Act 1974, in respect of the system used to distribute their publications in New South Wales (NSW) and the Australian Capital Territory (ACT). A substantially similar system was in operation in Victoria. 